heaven. He then proceeds to examine these ideas as seen in the architecture of both East and West. Following from these more general considerations, he goes on to consider the more detailed aspects of building, linking up both ornament and style with magical beliefs and the deeper mental processes deriving from the unconscious mind of the master builders. It is here that Mr. Lethaby is at pains to show that modern architecture, when it attempts to copy the past, has lost its soul. To him these sham styles are, as he so graphically puts it, the mere "grimaces of grown-ups". The age of magic has passed: what remains is, to the author of this illuminating book, the mystery of reality, and although mysticism and an outmoded view of the universe have passed away, both mystery and beauty are still left in service and science. If the modern builder is able to achieve a high functional beauty, then he will be able to show in his own architectural creations the same kind of inspired and creative work that Mr. Lethaby has shown to exist in the great buildings and decorative architecture of the ancient world.

F. J. Dingwali

\section{BOTANY OF BRITISH HILLS}

\section{Mountain Flowers}

By John Raven and Dr. Max Walters. (The New Naturalist: a Survey of British Natural History.) Pp. $x v+240+40$ plates. (London : William Collins, Sons and Co., Ltd., 1956.) 25s. net.

$\mathrm{T}$ HW New Naturalist series has proved a potent force in stimulating popular interest in British field natural history during the post-war years, and this latest addition is well in the best tradition of its predecessors--at once informative, authoritative and eminently readable. Already in the series there has appeared a classic concerned with the vegetation of the higher parts of the British Isles in Prof. W. H. Pearsall's "Mountains and Moorlands" ; the present volume, as its authors affirm, is scarcely comparable with. that of Pearsall as a scientific study, but it is nevertheless in many respects complementary, concerned as it is with the floristic rather than the ecological aspects of the mountain flora.

The book is written in two principal sections : a general one in which the history of the botanical exploration of the British mountains is reviewed and. some account given of the nature and history of their flora, and a regional one in which characteristic species of the more important mountain systems of the British Isles are described and discussed. In the appendixes, the authors provide lists of the mountain flora with distribution maps for several species, and keys for the identification of three critical genera with severul representatives on the British hills, Hieracium, Alchemilla and Salix.

The chapters concerned with the environment, nature and origins of the British mountain flora in the general section are the work of Dr. Max Walters. Ho presents the ecological features of montane habitatis starkly and in rather general terms; for an appreciation of the subtlety of the interaction of organism and environment in the communities of the hills, the reader would do well to follow his advice and consult other books of the New Naturalist series, notably those of Gordon Manley and of Pearsall. Dealing with the general biology, distributions and origins of mountain plants he is much more at home. Chapter 4 should be particularly informative to naturalists without access to professional journals, containing, as it does, an excellent general account of the trend of contemporary thinking about the history of the mountain species of Britain. Included therein is a survey of the evidence obtained from the investigation of Quaternary peat deposits-evidence which has so convincingly confirmed the view of Edward Forbes, of more than a century ago, that the arctic and alpine elements of the British flora, now mostly restricted to the mountain summits, are essentially the residues of a tundra type of vegetation once widespread, even in the lowlands, during the later stages of the glaciation.

Mr. John Raven contributes the historical introduction, and a number of pleasantly written chapters in the regional section. $\mathrm{He}$ is evidently a great lover of rare plants, and one who gains much pleasure from the hunt-the-slipper element so conspicuous in mountain botany. He has a lively sense of the principle of relative rarity-that what matters in extracting the maximum entertainment from plant hunting is not so much how common a plant is in area $A$, but how difficult it is to find at all in area $B$. Perhaps, however, he does not carry the principle far enough, for his disparaging comments on the general poverty of the Irish mountain flora awaken a defensive reaction in at least one of his readers.

Both authors are repeatedly at pains to stress the need for preserving what remain of our mountain plants, and are commendably reticent about localities for rarities. Nevertheless, one is uncomfortably aware of the grim possibility that a book like this, by its very success in popularizing the British mountain flora, may increase the threat to its continued existence if it results in even more profligate collecting. It must be agreed, of course, that a good deal of the damage has been done and is being done by agents other than collectors; even the weights of dried montane herbage in herbaria must be insignificant compared with the tons converted over the years into mutton. But in the present situation where the 'best' mountain plants often survive happily enough in minor oases, inaccessible to sheep and fire although surrounded by burnt and grazed deserts, it is the collector who is their most severe enemy. Furthermore, it is not the indiscriminating tyro who forms the greatest menace to the many mountain species which are distinguished only by their rarity, but rather the type of expert who, in his vanity, imagines that the needs of his particular herbarium or his special research privilege him to ignore the moderation in collecting which he would so severely enjoin upon others.

As one now expects from the New Naturalist volumes, the photographic plates, colour and monochrome, are mostly of a high standard. Some perhaps lack the sparkle that a touch of sunshine would have given, but who would deny that this is appropriate enough in portraits of inhabitants of the British hills. Most of the illustrations are in fact of native individuals. Of the exceptions, it is unfortunately understandable enough why it was necessary to visit the Austrian Alps for a photograph of Pinguicula alpina, but it seems a little superfluous to have journeyed so far as North Greenland for a picture of so accessible a British mountain plant as Silene. acaulis. In the interests of newcomors to mountain botany, some indication of scale might well have been given for the plates. J. HESLOP-HARRISON 